http://dx.doi.org/10.11646/zootaxa.3640.3.6

http://zoobank.org/urn:lsid:zoobank.org:pub:1348B15E-CF25-42F2-9399-742B52C46968

\title{
The second known specimen of Monodelphis unistriata (Wagner) (Mammalia: Didelphimorphia), with redescription of the species and phylogenetic analysis
}

\author{
RONALD H. PINE ${ }^{1}$, DAVID A. FLORES ${ }^{2} \&$ KURT BAUER ${ }^{3}$ \\ ${ }^{1}$ Biodiversity Institute, 1345 Jayhawk Boulevard, University of Kansas, Lawrence, Kansas 66045, U.S.A.; and Division of Mammals, \\ Field Museum, Chicago, Illinois 60605-2499, U.S.A.E-mail: ronpine@mac.com \\ ${ }^{2}$ Museo Argentino de Ciencias Naturales "Bernardino Rivadavia”, Av. Ángel Gallardo 470, CP 1405, Buenos Aires, Argentina. \\ E-mail:dflores@macn.gov.ar \\ ${ }^{3}$ Naturhistorisches Museum Wien, Burgring 7, 1010 Wien, Österreich 0431521770
}

\begin{abstract}
Very little information exists relevant to the species grouping and phylogenetic relationships of the opossum genus Monodelphis Burnett. Of the clearly distinct named species, the least information is available for M. unistriata (Wagner), one of the world's most poorly known species of mammals. Extant specimens consist of the Brazilian holotype of a skin now without a skull and dating from almost 200 years ago, and a second specimen with skin and incomplete skull dating from over a hundred years ago and from Argentina. The most recent published notes on the holotype date from well over half a century ago and, all told, such notes, the earliest dating from 1842, add up to a highly fragmentary and contradictory picture. No observations whatsoever have ever been published for the second and more complete specimen. Also, no hypotheses have ever been made concerning the intrageneric affinities of $M$. unistriata and such affinities have also been obscure throughout the genus. Herein, we provide a detailed redescription of M. unistriata, the first published images of specimens, and the first account, beyond the previous few most vague and incomplete remarks, of the morphology of the skull. In an effort to ascertain the phylogenetic affinities of M. unistriata, we performed a combined molecular (cytochrome $b$ ) and nonmolecular (postcranial, cranial, integument, and karyotypic characters) parsimony analysis incorporating 27 species of didelphids, including 11 of Monodelphis. Our results strongly support the monophyly of Monodelphis, and place M. unistriata as sister group to M. iheringi, among the included species.
\end{abstract}

Key words: Didelphidae, systematics, Brazil, Argentina

\section{Resumen}

Existe poca información sobre la mayoría de las especies del grupo monofiletico Monodelphis Burnett. De las especies descriptas, la menor cantidad de información disponible es para M. unistriata (Wagner), uno de los mamíferos menos conocidos del mundo. Los especímenes existentes consisten en el holotipo proveniente de Brasil, una piel sin cráneo de casi 200 años, y un segundo espécimen con piel y cráneo incompleto de al menos 100 años, proveniente de Argentina. La nota más reciente publicada sobre el holotipo tiene más de medio siglo, ofreciendo figuras contradictorias e información altamente fragmentaria. Ninguna observación ha sido publicada para el segundo y más completo espécimen. Además, no se ofrecieron hipótesis acerca de las afinidades intragenéricas de $M$. unistriata, y tales afinidades han sido oscuras también para todo el género. En este trabajo ofrecemos una detallada redescripción de M. unistriata, las primeras imágenes publicadas de los especímenes, y la primera descripción, más allá de algunas observaciones anteriores incompletas, de la morfología craneana. En un esfuerzo por determinar las afinidades filogenéticas de M. unistriata, realizamos un análisis de máxima parsimonia combinado caracteres moleculares (citocromo $b$ ) y morfológicos (craneanos, postcraneanos, tegumento y cariotipo), incorporando 27 especies dedidélfidos, incluyendo 11 de Monodelphis. Nuestros resultados apoyan fuertemente la monofilia de Monodelphis, y ubica a M. unistriata como grupo hermano de M. iheringi, entre las especies incluidas.

Palabras clave: Didelphidae, sistemática, Brasil, Argentina 


\section{Introduction}

The short-tailed opossum genus Monodelphis Burnett includes 25 named species, including several recently described (Solari 2007, 2010; Solari et al. 2012; Pine \& Handley 2008; Voss \& Jansa 2009; Vilela et al. 2010; Pavan et al. 2012; Solari et al. 2012; Voss et al. 2012). The considerable morphological diversity found in the genus has sometimes been used to justify recognition of species-groups (e.g., Solari 2007, 2010; Carvalho et al. 2011; Pavan et al. 2012), but the monophyly of the genus is well supported by genetic and morphological characters (e.g., Flores 2009; Voss \& Jansa 2009; but see Solari, 2010, Solari et al. (2012). Hershkovitz (1992) treated the genus as the sole constituent of a subfamily (Monodelphinae), in recognition of its distinctness, although without a phylogenetic rationale. Goin and Rey (1997) regarded Monodelphis as representing a radiation of opossums specialized for a relatively carnivorous diet, and closely related to the fossil Thylatheridium Reig (see also Reig 1957; Reig et al. 1987).

The interrelationships of the species and the taxonomic status of several terminals are currently under investigation. Solari (2007), for example, assessed the phylogenetic relationships within the adusta complex, showing that most species do indeed represent monophyletic and statistically supported groups. To date, the species considered to be in the genus are: $M$. adusta (Thomas), M. americana (Müller), M. arlindoi Pavan et al., M. brevicaudata (Erxleben), M. dimidiata (Wagner), M. domestica (Wagner), M. emiliae (Thomas), M. gardneri Solari et al., M. glirina (Wagner), M. handleyi Solari, M. iheringi (Thomas), M. kunsi Pine, M. maraxina Thomas, M. osgoodi (Doutt), M. palliolata (Osgood), M. peruviana (Osgood), M. reigi Lew \& Pérez-Hernandez, M. ronaldi Solari, M. rubida (Thomas), M. sanctaerosae Voss et al., M. scalops (Thomas), M. theresa Thomas, M. touan (Shaw), M. umbristriata (Miranda-Ribeiro), and M. unistriata (Wagner) (see Solari 2007; Pine \& Handley 2008; Voss \& Jansa 2009; Vilela et al. 2010; Pavan et al. 2012; Solari et al. 2012; Voss et al. 2012).

In 1842, Wagner named Didelphys unistriata from "Ytarare" (= Itararé at $24^{\circ} 07^{\prime} \mathrm{S}, 49^{\circ} 20^{\prime} \mathrm{W}$ ), São Paulo, Brazil, on the basis of a single stuffed skin, which at that time had a skull or portions of a skull inside, of an adult male short-tailed opossum deposited in the Vienna Museum and collected by Johann Natterer in 1821 on the fourth of his 10 tours through Brazil (Pelzeln 1883; Vanzolini 1993). The type specimen and the report of a second specimen with skull are the unique specimens representing this rare species, whose detailed morphology and phylogenetic position have remained unknown.

Herein, we have undertaken a critical review of prior treatments of $M$. unistriata and provided a detailed morphological redescription of the single known (and incomplete) extant skull, and attempted to ascertain the phylogenetic affinities of this species by scoring its morphological characters in the data matrix most recently used in didelphid phylogeny (Voss \& Jansa 2003, 2009), concatenated with additional postcranial characters (see Flores 2009) and genetic evidence (cytochrome $b$ gene).

\section{Material and methods}

In redescribing the skin and skull of the type and of an additional specimen of $M$. unistriata, we utilize Ridgway's (1912) color terminology and follow Wible's (2003) anatomical nomenclature. We compared the skull of $M$. unistriata with those of other species of Monodelphis (table 1) which are potentially sympatric with it in southern South America and with those of closely related species, according to our phylogenetic results (see below): $M$. dimidiata, M. domestica, M. iheringi, M. kunsi, M. scalops, and M. sorex (Hensel)—see Appendix 1-and critically reviewed all prior treatments of Monodelphis unistriata. Although recent genetic analyses (Solari 2010; Vilela et al. 2010) point to conspecificity of M. dimidiata with $M$. sorex, we treated the latter as a valid species in our comparative and phylogenetic analyses, based on the morphology of specimens from Misiones Province (Argentina), provisionally identified by us as M. sorex (see Appendix 1). In addition to the differences in pelage, previously reported (e.g., Massoia et al. 2000; Pine \& Handley 2008), cranial morphology of adult male $M$. dimidiata differs in several respects from that of adult male $M$. sorex as understood by us (e.g., M. dimidiata has a much greater interorbital constriction than $M$. sorex; see table 1 for additional characters). Recent published data also suggest a species complex for M. domestica (Caramaschi et al. 2011), with two clades in Brazil. Specimens we examined of these apparent taxa (see Appendix 1) come from southwestern Brazil, Paraguay, and northern Argentina, which represent areas closely associated with the Cerrado and Pantanal ( clade A in Caramaschi et al. 


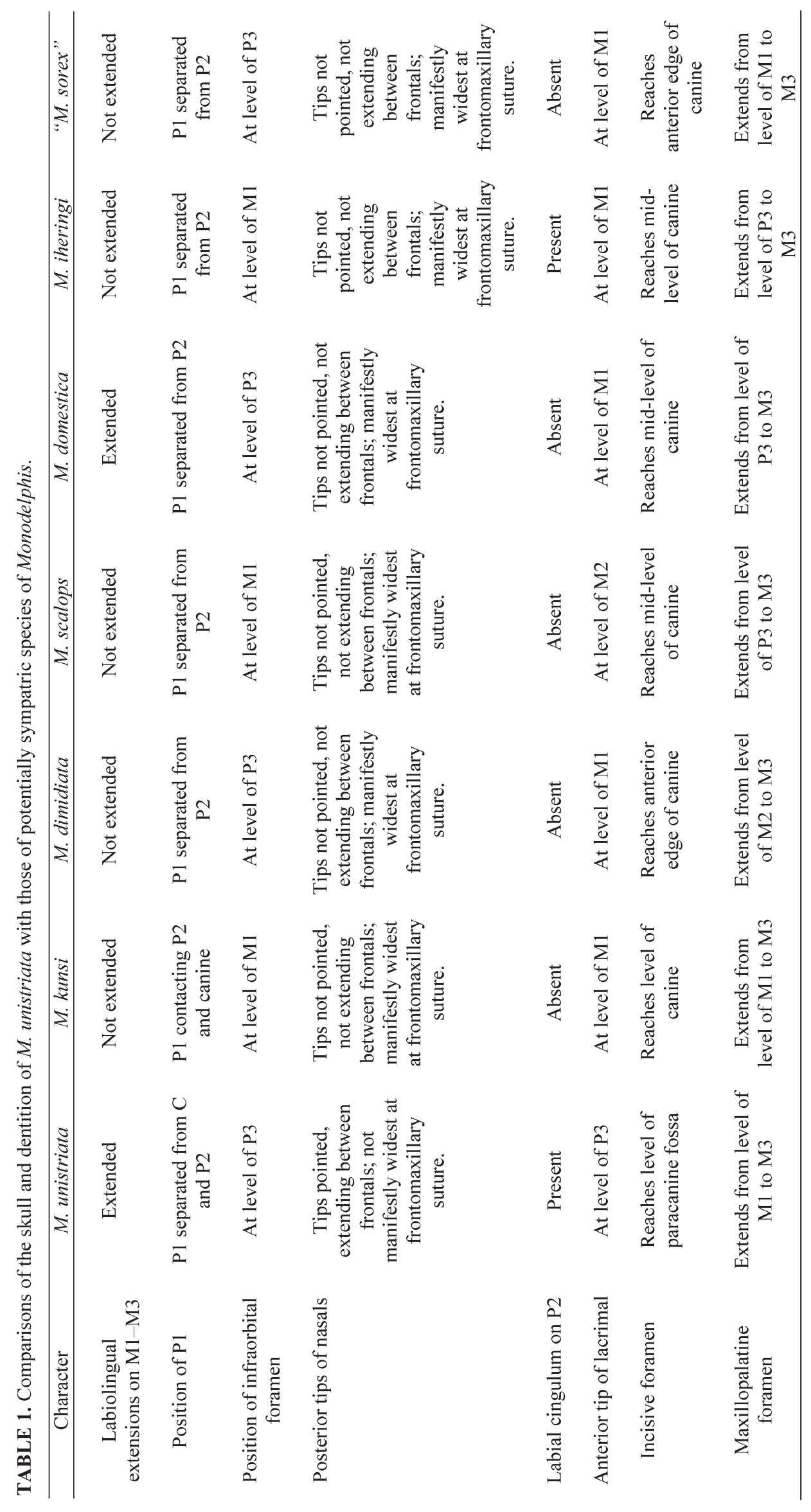


2011) and which include the type locality (Cuiabá, Brazil) for $M$. domestica, and thus our voucher specimens correspond to $M$. domestica sensu stricto. Similarly, our voucher specimens of M. brevicaudata come principally from southern Venezuela, and, according to the recent study by Pavan et al. (2012), the M. brevicaudata of authors is a species complex, with M. brevicaudata sensu stricto being found this region.

Although sequences for $M$. unistriata are unknown to date, we considered 26 cytochrome- $b$ sequences published in GenBank (901bp), concatenated with 129 nonmolecular characters defined by Voss \& Jansa (2009) and 114 postcranial characters described by Flores (2009). Sequences were edited and hand-aligned using the BioEdit software (Hall 1999). In the taxonomic sample analyzed, we added the additional species M. dimidiata, M. domestica, M. iheringi, M. kunsi, M. scalops, and "M. sorex" to the previous phylogenetic analyses that considered several species in the genus and this allowed us to integrate their morphological data with genetic sequences in our data-matrix. However, the postcranial morphology of the additional species of the genus is known only for $M$. kunsi (see below). We treated 11 species of Monodelphis in the ingroup and 16 didelphid species in the outgroup, including representatives of all major clades in Didelphidae (Voss \& Jansa 2008) and rooted in Glironia venusta. For our phylogenetic treatment, we executed a parsimony analysis using the program TNT (Goloboff et al. 2004) to search for optimal trees under equal weights. We conducted heuristic, unconstrained searches for optimal trees, using tree bisection-reconnection (TBR) branch-swapping in each of 100 replications of random taxon addition sequences and keeping up to 10 trees per replication. A second TBR round was applied to each of the optimals in order to increase the confidence of finding all topologies of minimum length. Zero-length branches were collapsed and strict consensus trees were generated. Clade support was estimated using absolute Bremer support (Bremer 1994), the values of which were calculated following the approach of Flores (2009), in order to prevent overestimation of support values. Specifically, we implemented a strategy for obtaining suboptimal trees in seven successive stages in which 2000 suboptimal trees were saved in each stage. Thus, in our analysis, a sample of $\geq 14,000$ suboptimal trees was used to calculate absolute Bremer support. In this way, we also sampled several suboptimal trees that could be overlooked in a less careful selection of suboptimals, which would lead to overestimated support values.

\section{Results and discussion}

As indicated above, the holotype (Fig. 1A) is still in existence and it is still housed in the Naturhistorisches Museum Wien (catalog number NMW B 1063). Natterer's catalog entry and his tiny original field tag are the only surviving original records. The specimen now consists of but a skin (without skull) in quite good condition. The skin of the right hind foot and the proximal part of the scrotum are broken but both are still attached to the skin. The tail still has the vertebrae inside and forms a downward bending hook. From its present form, it is clear that the skin (along with other Natterer specimens) was reworked - there is no official record of this occurring, but Thomas (1888) saw it with parts of the skull still inside and Miranda-Ribeiro (1936) did not mention dental characters at all. From this we deduce that the skull or rostrum was taken out during this reworking sometime between 1885-87 and 1911. Sometime after Miranda-Ribeiro's visit of 1911, the small opossums in the Naturhistorisches Museum Wien must have been borrowed by and partly reworked at the Berlin Museum, most likely in connection with Matschie's paper of 1916, because some of the old NMW specimens of Monodelphis domestica (Wagner) and the type of Monodelphis glirina (Wagner) have the characteristic make and labeling of Berlin skins of the period. Since no one subsequent to Thomas (1888) mentioned dental or cranial characters, the skull might have been lost during or after removal from the skin. Judging from Thomas's short notes, only fragments of jaws may have remained from the field preparation in any event. In recent decades, the entire mammal collection in the Naturhistorisches Museum Wien has been checked and rearranged, and so there is no chance that the missing fragmentary skull may yet turn up. Bauer has compared the holotype with several specimens of several species, including types, and these specimens are listed in Appendix 1.

The specimen has been reworked at least twice-first, after receipt at the museum, it was mounted on a stand and then later it was remade into a study skin. As noted above, we must assume that the dental and cranial remains that had remained in the skin were lost during the second remake. Measurements in millimeters and taken from the present specimen, which does not give the impression of having been overstuffed or the reverse, are "European style": head and body, 141.1; tail, 62.4; hind foot s. u., 15.5; ear (crumpled), 8.2; "American style"; total length 
(following dorsal line), 211.0; total length (following flat ventral line-most likely the best match to the measurement taken from the fresh specimen flat on its back), 199.6; hind foot c. u., 16.2; ear (crumpled), 5.3. [For illustrations showing "European" and "American" measurements, see Martin et al. (2001)].

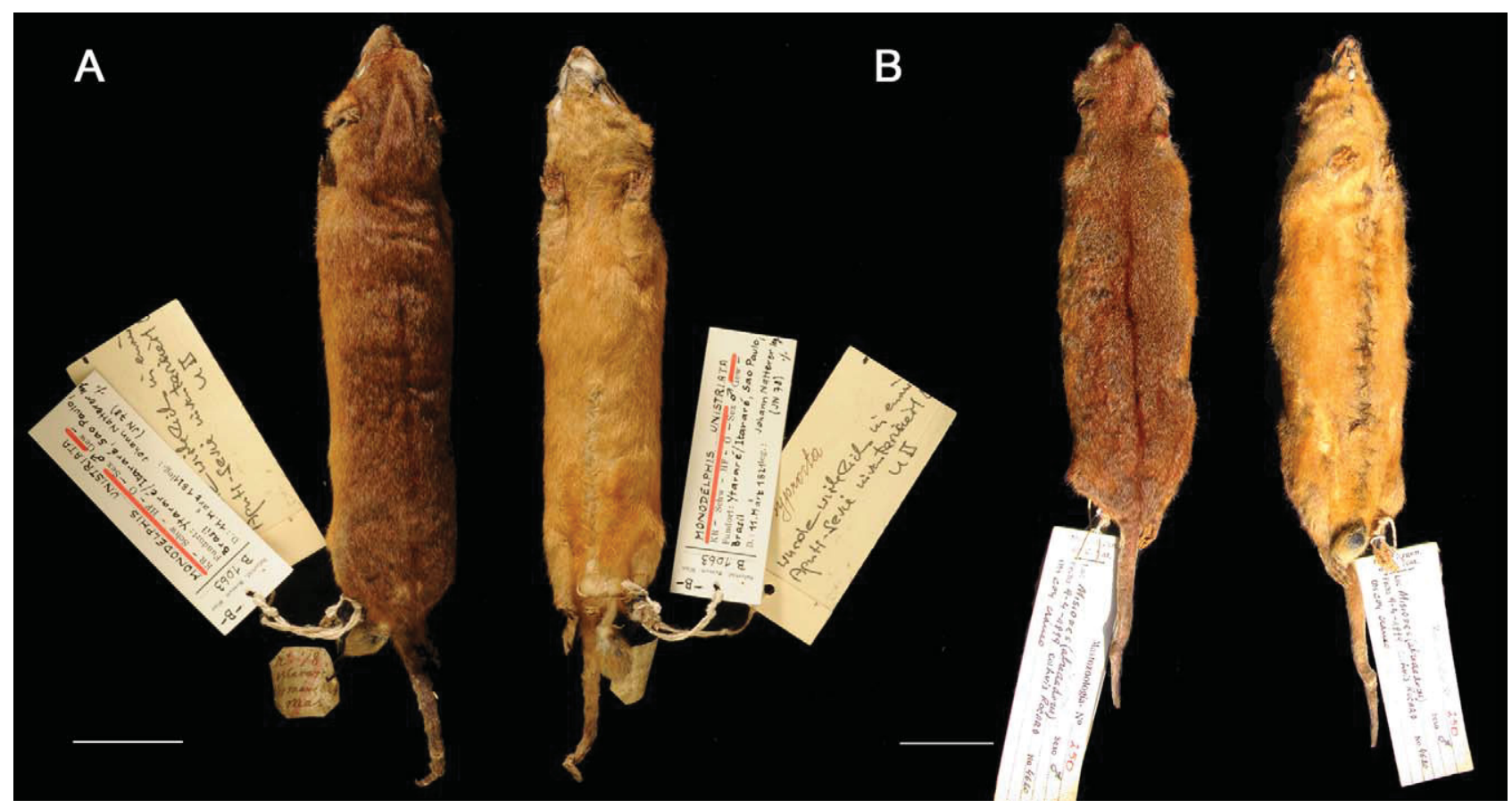

FIGURE 1. A) Dorsal and ventral views of skin of holotype of Monodelphis unistriata (NMW B 1063). Photo by Friederike Spitzenberger of Naturhistorisches Museum Wien. B) Dorsal and ventral views of skin of second known specimen of $M$. unistriata (MACN 250). Photo by David Flores. Scale bars: $20 \mathrm{~mm}$.

The holotype of M. unistriata appears to be shorter-legged than the specimens to which it was compared, but it is unclear as to the extent that this may be an artifact of preparation. Because all of the other specimens from Natterer's expedition went through the same hands, there may be a real difference here. The front feet are robust and broad, rather like those of the somewhat larger specimen of M. glirina. They are smaller in the M. domestica and narrow and slender in an "M. sorex" from Rio Grande do Sul. The hind feet are damaged but are not obviously different from those of the other specimens. They are clearly narrower than the front feet. The comments which have been made on the tail are difficult to understand. It is obvious that the tail had dried up or been deformed so that the vertebrae could not be extracted. It appears that in the first third of the caudal vertebral column there is some thickening resulting from injury and one might suppose that the animal may have been captured with the tail in this more or less hooked and stiffened condition. This seems not to have been the case, however, because Natterer's notes concern only the pelage of the tail. Translated, they read, "tail covered by short...hairs that are somewhat longer at the base". There is certainly no basis for Wagner's interpretation - the dorsal and ventral tail hairs are not different structurally or in position. If more of the ventral hair looks depressed, then this is simply the result of that hair being on the inside of the curve.

The hair of the holotype is short and rather stiff. The longest hairs dorsally measure $4.6 \mathrm{~mm}$. They are a bit shorter and somewhat stiffer than in the specimen of M. americana and are distinctly more so in comparison with the other specimens. With the aid of F. Spizenberger, various color designations were decided upon-Ridgway: middorsal stripe Cinnamon Brown; the rest of the back, owing to grizzling, hard to define but the overall effect is between pale Sanford's Brown, Amber Brown, and Xanthine Orange; lateral coloration Ochraceous Tawny; ventral coloration - breast behind forefeet and the area before hind feet (some 15-20 mm long)-the same, then the remainder of the venter of the same tone but somewhat paler and less saturated. Munsell Soil Color Charts: middorsal stripe Dark Reddish Brown; dorsum (total impression) Reddish Brown; lateral coloration between Reddish Yellow 7 and Strong Brown 7; belly Reddish Yellow 7.

The grizzling of the dorsum results from there being pale grayish bases, a whitish-beige central band, and long rufous tips which darken to near blackish at the very end of the longer individual hairs. The middorsal stripe is 
about $2.2 \mathrm{~mm}$ broad. It begins behind the shoulders and ends on the rump about $9.5 \mathrm{~mm}$ before the base of the tail. The rufous dominates - the paler central band on the individual hairs is scarcely indicated. One gains a faint impression of the stripe being in a slight furrow (or of its hair being a trifle shorter), but this seems partly an optical effect, partly an artifact of the make (the V-shaped mark seen on the crown results from two sharp folds that are certainly artificial also). The flanks and ventral pelage are unicolor, in the more saturated areas with somewhat darker tips. The short hair on the dorsal side of the tail and of the limbs is dark grayish-brown, on the ventral side of the tail and the scrotum, buff. The longer tail hair on the first $12 \mathrm{~mm}$ above and first $10 \mathrm{~mm}$ below is like that on the body.

The Argentine specimen of Monodelphis unistriata. A second specimen of Monodelphis unistriata (Figs. 1B-2), also of an adult male, is deposited in the Museo Argentino de Ciencias Naturales "Bernardino Rivadavia" in Buenos Aires and is cataloged as MACN 250. According to its tag, this specimen is from "Misiones, alrededores (sic-no second set of quotation marks), and was taken by Luis Boccard on 9 April 1899. Various prior treatments that discuss the marsupials of Argentina (e.g., Cabrera 1958; Olrog \& Lucero 1981; Massoia et al. 2000; Flores 2003, 2006; Flores et al. 2007) did not mention this species for the country. Recent authors (Chebez \& Massoia 1996; Gardner 2005; Canevari \& Vaccaro 2007; Pine \& Handley 2008), however, on the basis of the MACN specimen, supported the idea of M. unistriata as possible for or present in northeastern Argentina (Misiones Province), in spite of the uncertainty of the geographical record. In 1899, the historical name "Misiones" would have been applied to several areas in what are now northeastern Argentina and southeastern Paraguay, and at present is still the name used for a province in Paraguay. However, we are sure that the specimen came from Argentina because Boccard collected only in what is now Argentine territory. Olrog and Lucero (1980) made no mention of this species in Argentina, although they did list Monodelphis domestica; "Monodelphis touan" $[($ Shaw $)]$, presumably = misidentified "M. sorex" or Monodelphis scalops, Monodelphis americana, Monodelphis henseli - their specimens presumably = "Monodelphis sorex" in part and Monodelphis dimidiata in part; and Monodelphis fosteri [Thomas], apparently = Monodelphis dimidiata . Certain recent works (e.g., Massoia et al. 2000; Flores 2003, 2006; Flores et al. 2007) did not mention M. unistriata for Argentina, but did list M. dimidiata, M. domestica, M. americana/M. iheringi (= M. iheringi), M. kunsi, M. scalops, and "M. sorex". Monodelphis unistriata now constitutes the seventh species of Monodelphis, reported for Argentina. Canevari and Vaccaro (2007) provided a brief description of the species and the only figure that we know of that has been prepared of it.

The skin of MACN 250 (Fig. 1B) is in good condition and its characteristics are similar to those described for the holotype. The fur of the Argentinean specimen is shorter, denser, and more velvety than in M. dimidiata. There is no heightened reddening of the pelage on the head and/or rump as in some Monodelphis (e.g., emiliae or scalops). The dorsal fur is provided with a dark drabby basal band, a middle band of pale buff, and a terminal band of cinnamon. The chestnut middorsal stripe begins at the level of the shoulders and continues to the base of the tail. The fur is self-colored orangish buffy laterally and ventrally. The scrotum is heavily pigmented. These characteristics are almost exactly the same as those of the holotype. This distinctive combination of characters leaves no doubt that Wagner, Pelzeln, Thomas, and Miranda-Ribeiro were correct in recognizing this animal as a species separate from other named opossums.

The Argentine specimen is prepared as a "skin and skull" and is of an adult of age group 5-6 (see Pine et al. 1985), which groups are characterized by: "age class 5, all permanent teeth erupted but M4 with little or no wear; age class 6, M4 with moderate wear, $\mathrm{m} 4$ with little or no wear". Except for much of the left zygomatic arch, palate, rostrum, and mandible, all portions of the skull are missing, and they represent the only extant evidence of the skull morphology of M. unistriata. Skull measurements (in millimeters), taken as given by Pine (1981) and by Pine et al. (1985) are: maxillary toothrow, 13.4; M1-M4, 5.9; length of mandibular ramus, 27.1; mandibular toothrow, 15.4; mandibular depth, 2.9 .

Although the skull of MACN 250 (Fig. 2) is fragmentary, the palate, rostrum, mandible, and toothrows are in good condition (although coronoid and angular processes of mandible broken). The rostrum is elongated, but robust in dorsal view; the paracanine fossa is deep, limited anteriorly by the premaxilla and posteriorly by the maxilla. The premaxilla has a wedge-shaped caudal extension reaching to the level of P1. The nasals are proportionally wide and widen further posteriorly at the frontomaxillary suture; the lacrimal is anteriorly extended, reaching the level of the infraorbital foramen and P3. There is no supraorbital beading and there are no postorbital constrictions. Incisive foramina extend posteriorly to level of paracanine fossa; maxillopalatine foramina extend from level of P1 to level of P3. The fragmentary jugal bears a distinct lateral border for the masseteric insertion. 
Mandible is slender, and although the coronoid and angular processes are broken, the masseteric fossa and articular condyle can be seen to be well developed.

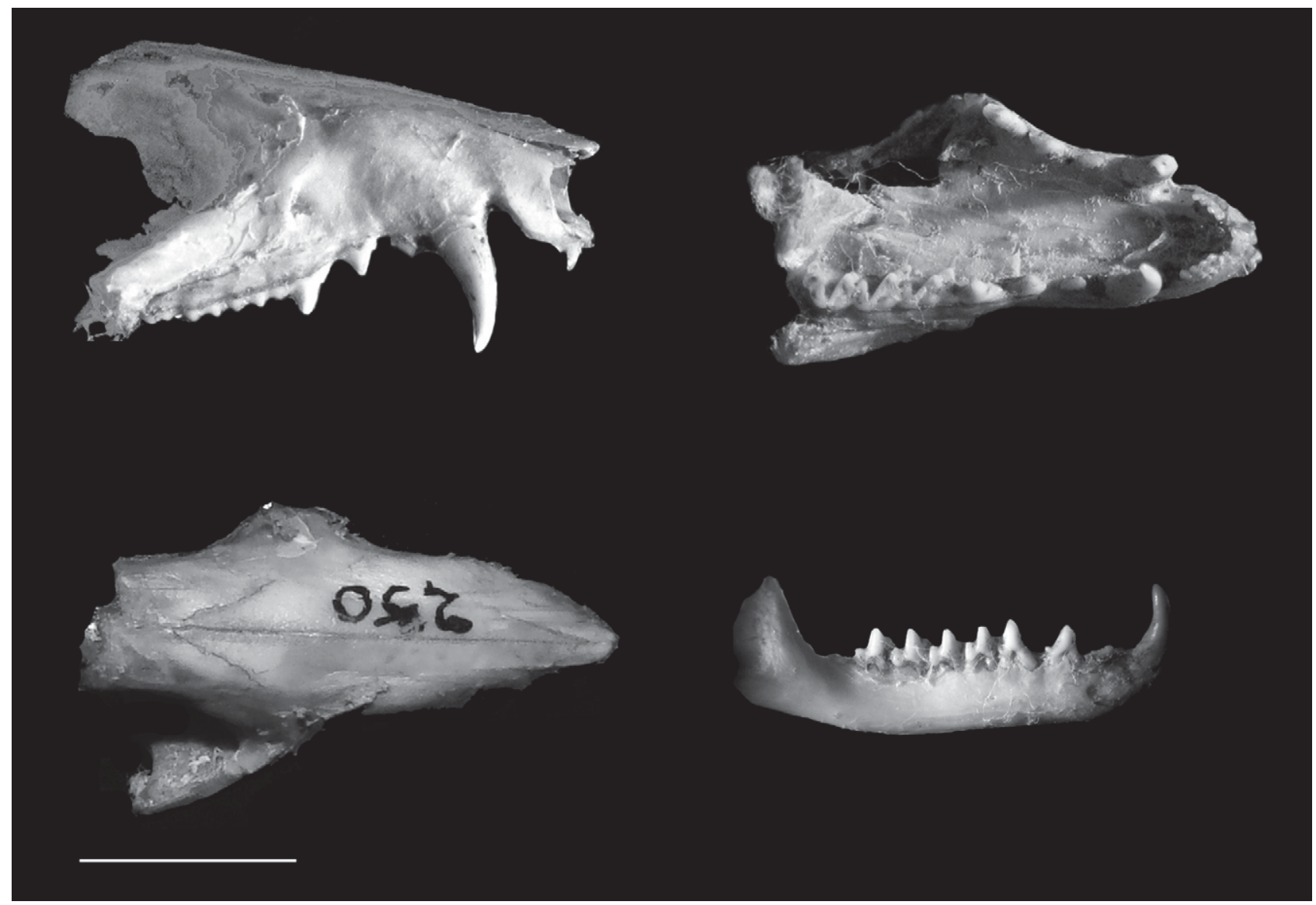

FIGURE 2. Lateral (above, left), ventral (above, right), and dorsal (below, left) views of incomplete cranium, and lateral (below, right) view of incomplete right dentary of the only known extant skull of $M$. unistriata (MACN 250). A distinctive combination of characters is shown, i.e., first upper premolar separated from canine and P2; infraorbital foramen placed at level of P3; posterior tips of nasals projecting between frontals, being not manifestly widest at frontomaxillary suture; and anterior tip of lacrimal at level of P3. Scale bar: $5 \mathrm{~mm}$.

I1 is the longest upper incisor and I5 is the widest. Upper canine well developed, without posterior cingulum. A small diastema between the P1 and P2; P1 the smaller and with a tiny posterior cingulum. P2 intermediate in size, with small cingula fore and aft; P3 taller, also with two small cingula. Proceeding posteriorly, M1-M3, the occlusal elements become labiolingually more elongated, especially the paracrista and metacrista. In M1-M3, the metacone is the tallest cusp, and the protocone is taller than the paracone only in M1 and M2; in M3 protocone and paracone subequal in size. Anterolabial cingula well developed, especially on M3, and stylar cusps present, with B and D the most developed. M4 exceptionally compressed antero-posteriorly, but about as wide labiolingually as M3 and with paracone the tallest cusp and paracrista well developed.

Lower incisors small, with i1 the widest. Lower canine well developed, without apparent cingulum. First lower premolar exceptionally small, with conspicuous posterior cingulum. Second lower premolar is taller, with a small anterior cingulum and larger one posteriorly. Third lower premolar the tallest, without anterior cingulum, but with well developed one posteriorly. In m1-m3, the talonids shorter than trigonids, but about as wide, and anterolabial cingula lower and poorly developed. Paraconids are the taller cusps, followed by the metaconids and paraconids; entoconids reduced; hypoconids and hypoconulids not well developed. On $\mathrm{m} 4$, the talonid strongly reduced.

A comparison of the skull of M. unistriata (Table 1) with skulls of adult (age group 5-6) male specimens of other species of Monodelphis which are potentially sympatric (i.e., M. domestica, M. dimidiata, M. scalops, M. kunsi, "M. sorex," and M. iheringi), also demonstrates that M. unistriata is a differentiated taxon with a unique combination of osteological characters. Compared with other species of Monodelphis, M1-M3 of M. unistriata (and of M. domestica) are more extended labiolingually, because of enlarged postprotocristae. In addition, P1 in $M$. 
unistriata is relatively widely separated from both the canine and P2, whereas, in the other species, $\mathrm{P} 1$ is manifestly separated only from P2, but nearly in contact with the canine. P2 of M. unistriata (and of M. iheringi) possesses a lingual cingulum, absent in the other species. In M. unistriata, the posterior tips of the nasals are acutely pointed, penetrating between the frontals and widening slightly at the frontomaxillary suture. In the others, the nasals are rounded posteriorly and are considerably wider at the frontomaxillary suture. The anterior tip of the lacrimal of $M$. unistriata reaches the level of $\mathrm{P} 3$, whereas in the others it reaches the level of M1, except in M. scalops, in which it reaches the level of M2. The infraorbital foramen in $M$. unistriata is at the level of $\mathrm{P} 3$, as in M. dimidiata, " $M$. sorex", and M. domestica, whereas it is at the level of M1 in M. scalops, M. kunsi, and M. iheringi. The incisive foramina of M. unistriata are short, reaching only to the level of the paracanine fossa, as is also the case in $M$. dimidiata and "M. sorex". The foramina in the other species are longer, reaching the level of the canines. The maxillopalatine vacuities are short in M. unistriata, reaching from M1 to M3, as in M. kunsi and "M. sorex"; in M. dimidiata they are shorter, extending from M2 to M3. In the others, they extend from P3 to M3. Upper and lower canines of $M$. unistriata rather long. The rostrum of $M$. unistriata resembles that of adult male $M$. dimidiata more than that of M. americana, and the affinities of $M$. unistriata could be closer to M. dimidiata than to other members of the genus.

Phylogenetic relationships of $M$. unistriata. A review of the literature will show that generic and subgeneric subdivision made of the Didelphidae, on the basis of morphology, has contributed little but confusion to an understanding of natural groups in what is now included in the genus Monodelphis. However, the monophyly of the genus has, in recent years, been clearly demonstrated (e.g., Jansa \& Voss 2000; Voss \& Jansa 2003, 2009; Jansa et al. 2006; Gruber et al. 2007; Flores 2009) in the course of a marked expansion of didelphid phylogenetic studies (e.g., Voss \& Jansa 2003, 2009; Solari \& Pine 2008; Flores 2009; Gutiérrez et al. 2010; Lim et al. 2010; Rossi et al. 2010; Carvalho et al. 2011; Pavan et al. 2012) involving new knowledge and interpretations of external and internal anatomy, new DNA sequence information from nuclear and mitochondrial genes, inclusion of a larger taxonomic sample, and taxonomic clarification of some polytypic groups. Solari (2010) and Solari et al. (2012), however, in their studies using the mitochondrial cytochrome $b$ gene, acquired results somewhat at variance with monophyly and genetic information for various species has yet to be acquired. In the case of M. unistriata, our lack of knowledge is a consequence of there being only two known specimens, both of which are over a hundred years old. Although genetic and postcranial information is currently unavailable, along with much other information, the existence of two complete skins and a partial skull allows a phylogenetic reconstruction in which the relationships of M. unistriata can be inferred.

In an unpublished morphological phylogenetic analysis performed by Flores (2003), in which the MACN specimen of $M$. unistriata was included in a diverse taxonomic sample of 46 species and in which 141 nonmolecular characters were considered, $M$. unistriata clustered with $M$. iheringi, being sister to the clade $M$. dimidiata-"M. sorex". In the present analysis, we scored, for M. unistriata, most of the 129 nonmolecular characters used by Voss and Jansa (2009, see Appendix 2). We scored thirty-seven morphological characters (1-3, 28-31, 50, 51, 56-61, 70-74, 76-85, 87, 99, 109, 116, 126-129) as missing, owing to unavailability of suitable material, and several characters as inapplicable ("-"). For instance, character 7 was inapplicable, as it is in other species in which fur surrounding the eye is not distinctively colored; character 27 was inapplicable as in other pouchless species; and character 53 as with other species without postorbital processes. The character states of Voss and Jansa (2009) concerning dorsal pelage patterns (their ch. 10, appendix 3) do not include that of $M$. unistriata (i.e., a single middorsal stripe), and so we added that as an extra condition. The four characters dealing with chromosomal fission/fusion events (126-129) were also scored as missing because no karyotype has been determined for this species.

Our scoring for M. unistriata and additional species of Monodelphis, for which morphological and genetic information is available to us (i.e., M. dimidiata, M. domestica, M. iheringi, M. kunsi, M. scalops, and "M. sorex"), based on the data-matrix defined by Voss and Jansa (2009) and by Flores (2009), is shown in Appendix 2. As mentioned in Methods, we ran a maximum parsimony analysis incorporating 27 species, following the criteria mentioned above.

The parsimony analysis resulted in 4 most-parsimonious trees ( 2483 steps; $\mathrm{CI}=0.60 ; \mathrm{RI}=0.77$ ). The internal relationships in general reflect those recovered for the major clades in Didelphidae, using Glironia venusta as root (Voss \& Jansa 2009). Indeed, one of the most probable phylogenetic positions of G. venusta is as sister to the rest of the didelphid crown group (Voss \& Jansa 2009). The monophyly and internal relationships of Monodelphis are in 
partial agreement with previous phylogenetic analyses performed on the genus (e.g., Solari 2010; Caramaschi et al. 2011; Solari et al. 2012). Our combined analysis strongly supports the genus Monodelphis as monophyletic (Fig. 3). Monodelphis brevicaudata, which appears to be a species complex (Pavan et al. 2012; Solari et al. 2012), occupies a basal position in the genus. Several clades within Monodelphis are strongly supported in the analysis, i.e., those composed of $M$. theresa-M. scalops; "M. sorex"-M. dimidiata, and the clade including the last plus (M. domestica (M. unistriata-M. iheringi). Although the evidence used to determine the phylogenetic position of $M$. unistriata is limited to some external characters and a fragmentary skull, our phylogenetic inferences based on combined characters suggest that there is a close relationship between M. unistriata and M. iheringi. Although both species have dorsal stripes (but in M. unistriata only a single one), this trait is also shared with $M$. theresa (sister of M. scalops in this analysis and in the topology recovered by Solari et al. 2012), M. americana, and M. umbristriata (Miranda Ribeiro) (the last two species not included in this analysis but recovered as sister species by Caramaschi et al. 2011), and M. gardneri (sister of M. americana according to Solari et al. 2012). Despite the poor degree of phylogenetic relationship recovered (Fig. 3), Monodelphis theresa and M. iheringi are quite similar, with the latter appearing to differ appreciably only in its flattened skull. Also, Monodelphis americana is very similar in markings and morphology to $M$. theresa. These species would thus form an eastern South American striped group, although M. umbristriata may prove to be conspecific with M. americana, which is also suggested in the topology obtained by Caramaschi et al. (2011) with molecular evidence. There is also now reason to believe that $M$. theresa is a junior synonym of M. scalops, with "theresa" being the temporarily striped young of M. scalops, as suggested by Gomes (1991) and Solari et al. (2012). We have seen photographs, of series of specimens of increasing age, provided by Nelson Gomes and others and which seem to show a transition in coloration from that of theresa to that of scalops. However, there may still be one or more unnamed small, striped species, the size of $M$. iheringi, but not having a flat skull, and which has/have been published on under the name theresa. One of these may have been used instead of true $M$. theresa in our and other recent phylogenetic analyses, thus explaining the wide separation seen, in these analyses, between animals called "scalops" and ones called "theresa". Recent genetic evidence (Solari et al. 2012), including that from the striped M. gardneri, indicates that in spite of external resemblance, species with dorsal stripes do not form a monophyletic group.

Solari (2010), in his study of phylogenetic relationships among Monodelphis, based on the mitochondrial cytochrome $b$ gene, found eight species groups and remarked "Support of the eight species groups in all [his]...phylogenetic analyses is remarkable...and merits further assessment of congruence with other nonmolecular datasets (e.g. morphology)". The present study can serve as a partial analysis of the desired concatenated (morphology + genetic evidence) dataset for comparison with Solari's (2010) results. Relationships shown in our analysis, with a diverse didelphid outgroup, differ from those arrived at in Solari's analysis, in some particulars. Solari found M. brevicaudata and M. domestica to be two of the constituents of his "brevicaudata species group" (also including M. glirina), an arrangement in accord with opinions also expressed by several authors (e.g., Patton \& Costa 2003; Pine \& Handley 2008; Caramaschi et al. 2011; Carvalho et al. 2011; Pavan et al. 2012; Solari et al. 2012), whereas in our topology such arrangement is not recovered. However, the position of M. peruviana is in agreement with previous topologies (e.g., Solari 2010; Solari et al. 2012), i.e., placed in a clade close to M. theresa and M. scalops. Another clear similarity between our results and those reported by Solari (2010), Pavan et al. (2011), and Solari et al. (2012) is the close relationship shown between M. kunsi and M. emiliae. However, in the ML topology recovered by Carvalho et al. (2011: Fig. 3), M. kunsi is sister species to M. adusta (not included in this analysis), or it is placed as a basal species not related to M. emiliae. As was mentioned above, we treated $M$. dimidiata and " $M$. sorex" as different species, based on clear morphological differences apparent to us (table 1), in spite of conclusions based primarily on recent genetic evidence (Solari, 2010; Vilela et al., 2010; Carvalho et al., 2011; Solari et al. 2012). However, and in partial agreement with these genetic analyses, our combined analysis does show these species as closely related and nested in a clade with $M$. iheringi, $M$. unistriata, and M. domestica (Fig. 3).We would expect only partial agreement between the topologies based on combined data-sets, as presented here, and those based on genetic evidence, not only because of the influence of the 243 morphological characters employed, but also owing to different samples of specimens from different areas. Morphological characters sampled to date are not sufficiently informative as to allow refined elucidation of the relationships in this genus. 


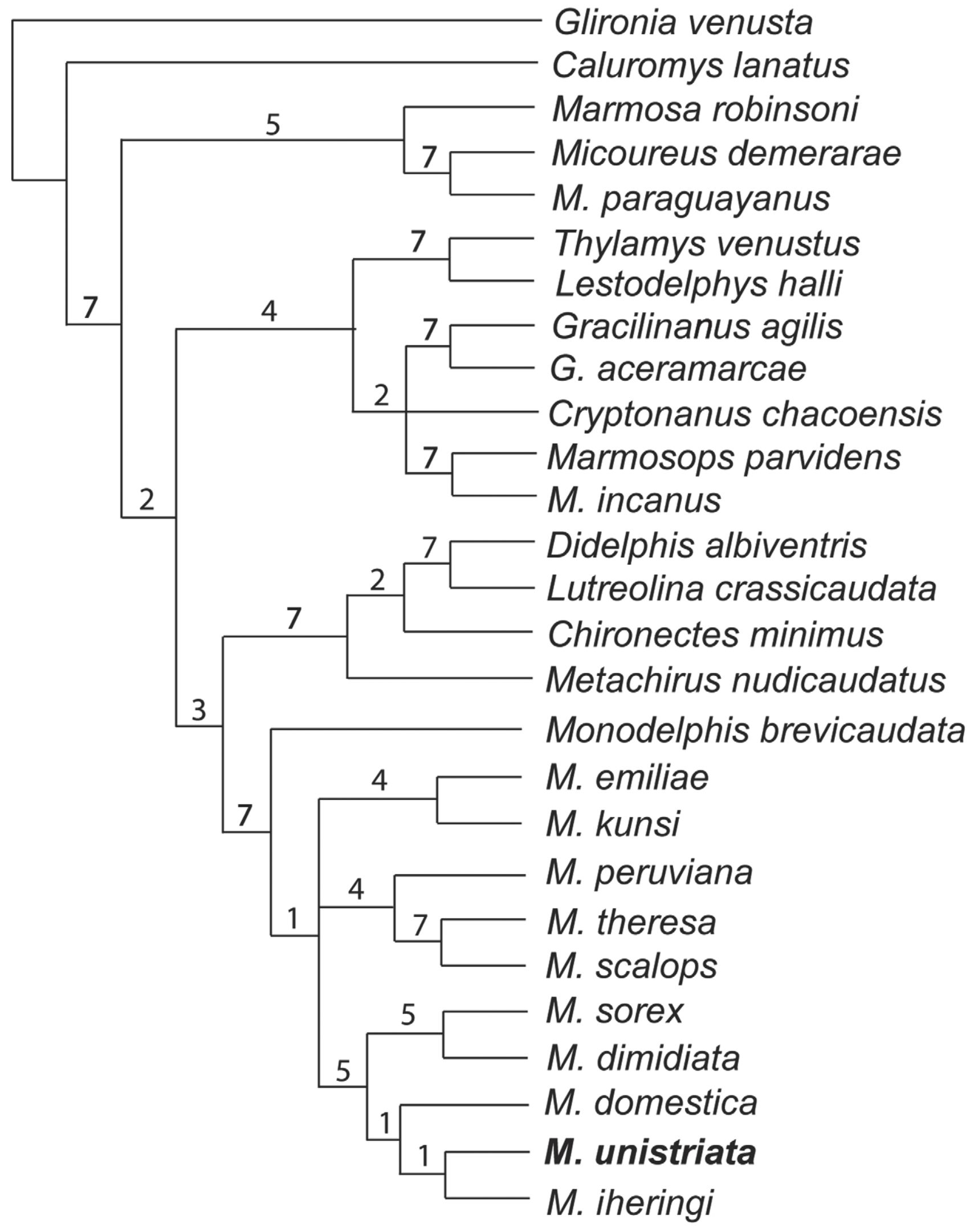

FIGURE 3. Strict consensus of 4 equally most-parsimonious trees obtained through an heuristic parsimony analysis of combined nonmolecular characters used by Voss and Jansa (2009), Flores (2009), and cytochrome $b$ sequences, enhanced by inclusion of M. dimidiata, M. domestica, M. iheringi, M. kunsi, M. scalops, and M. unistriata. Statistical values above branches refer to absolute Bremer support $(\geq 1)$. 
Unfortunately, in spite of ongoing collecting efforts in southern Brazil and northeastern Argentina, no additional specimens of $M$. unistriata are known to have been taken since 1899. It is possible that we are dealing with a recently extinct South American marsupial. As noted by Pine and Handley (2008: 106), however, there may be a third — or even more — specimens in Rio de Janeiro. This is because, in a table, Eisenberg and Redford (1999: 68) mentioned a specimen or specimens supposedly in either "the Museo, Rio de Janeiro" or the Field Museum, with "A single chestnut dorsal stripe". We have found no such specimen or specimens in the Field Museum and others have failed to find such in Museu Nacional in Rio de Janeiro. Although a close relationship between $M$. unistriata and $M$. iheringi was recovered in our topology, in the absence of additional specimens of M. unistriata, additional characters as well as inclusion of apparently related species (e.g., M. americana and M. umbristriata) will be necessary to ever more firmly ascertain the relationships of this enigmatic taxon.

\section{Acknowledgments}

We are grateful to Marta Piantanida, formerly of the MACN, for help and hospitality during Pine's visit there and to Sydney Anderson of the American Museum of Natural History and Rubén M. Barquez of the Colección Mamíferos Lillo for helping Pine make the necessary arrangements to examine specimens in Buenos Aires. The late Philip Hershkovitz of the Field Museum provided Pine with useful information concerning old-time European units of measurement. Beverly Morey of the University of Kansas Department of Geography helped with the manuscript, and John Stark, of the Illinois Mathematics and Science Academy (IMSA), helped Pine with some of the finer points of translating some of the German references. Friederike Spitzenberger and Simon Engelberger of the Naturhistorisches Museum Wien have been most helpful to us in various ways as has Anita Gamauf of that museum. Pine's work in Argentina was partially supported by IMSA. We thank all the curators who facilitated the study of the material under their care: Rubén Barquez (CML), Paula Jenkins and Daphne Hills (BMNH), Diego Verzi (MLP); Ricardo Ojeda (IADIZA); Sergio Bogan (CFA); Damián Romero (MMP), Rob Voss (AMNH) and Hein Van Grow (RMNH). The suggestions of Sergio Solari, Marcelo Weksler, and one anonymous reviewer improved the quality of this manuscript.

\section{References}

Bremer, K. (1994) Branch support and tree stability. Cladistics, 10, 295-304. http://dx.doi.org/10.1111/j.1096-0031.1994.tb00179.x

Burmeister, H. (1854) Systematische Uebersicht der Thiere Brasiliens, welche während einer Reise durch die Provinzen von Rio de Janeiro und Minas Geraës gesammelt oder beobachtet wurden von Dr. Hermann Burmeister. Säugethiere (Mammalia). Georg Reimer, Berlin, 1, x +342 pp.

Burmeister. H. (1856) Erläuterungen zur Fauna Brasiliens, enthaltend Abbildungen und ausführliche Beschreibungen neuer oder ungenügend bekannter Thier-Arten. Georg Reimer, Berlin, ix + 115 pp. +32 pls.

Burnett, G.T. (1830) Illustrations of the Quadrupeda, or Quadrupeds, being the arrangement of the true four-footed Beasts indicated in outline. Quarterly Journal of Science, Literature and Art, July to December, 1829, 336-353.

Cabrera, A. (1919) Genera Mammalium. Monotremata, Marsupialia. Museo Nacional de Ciencias Naturales, Madrid, 177 pp. +19 pls.

Cabrera, A. (1958) Catálogo de los mamíferos de América del Sur. Revista del Museo Argentino de Ciencias Naturales "Bernardino Rivadavia," Instituto Nacional de Investigación de las Ciencias Naturales, Ciencias Zoológicas, 4, i, iii-iv + $1-308$.

Cabrera, A. \& Yepes, J. (1940) Mamíferos Sud Americanos (vida, costumbres y descripción). Historia Natural Ediar, Compañia Argentina de Editores, Buenos Aires, 370 pp. +1 map +78 pls.

Cabrera, A. \& Yepes, J. (1960) Mamíferos Sud Americanos, Vol. 1. Historia Natural Ediar, Ediar S.A. Editores, Buenos Aires, 187 pp. +1 map +35 pls.

Canevari, M. \& Vaccaro, O. (2007) Guía de Mamiferos del Sur de América del Sur. Editorial L.O.L.A., [Literature of Latin America], Buenos Aires, 3 unnumbered +413 pp.

Caramaschi, F.P., Nascimento, F.F., Cerqueira, R. \& Bonvicino, C.R. (2011) Genetic diversity of wild populations of the grey short-tailed opossum, Monodelphis domestica (Didelphimorphia: Didelphidae), in Brazilian landscapes. Biological Journal of the Linnean Society, 104, 251-263.

http://dx.doi.org/10.1111/j.1095-8312.2011.01724.x

Carvalho, B.de A., Oliviera, L.F.B., Langguth, A., Freygang, C.C., Ferraz, R.S. \& Mattevi, M.S. (2011) Phylogenetic 
relationships and phylogenetic patterns in Monodelphis (Didelphimorphia: Didelphidae). Journal of Mammalogy, 92, 121133. http://dx.doi.org/10.1644/10-MAMM-A-075.1

Chebez, J.C. \& Massoia, E. (1996) Mammals of the province of Misiones. In: Chebez, J.C. (Ed.) Fauna Misionera. Catálogo Sistemático y Zoogeográfico de los Vertebrados de la Província de Misiones (Argentina). Editorial L.O.L.A. [Literature of Latin America], Buenos Aires, pp. 180-308.

Eisenberg, J.F. \& Redford, K.H. (1999) Mammals of the Neotropics. The central Neotropics. Volume 3. Ecuador, Peru, Bolivia, Brazil. The University of Chicago Press, $\mathrm{x}+609 \mathrm{pp}+19$ pls.

Flores, D.A. (2003) Estudio Taxonómico y Zoogeográfico de los Marsupiales de Argentina. Doctoral Thesis, Universidad Nacional de Tucumán, Argentina, 326 pp.

Flores, D.A. (2006) Orden Didelphimorphia. In: Barquez, R., Diaz, M. \& Ojeda, R. (Eds.), Mamiferos de Argentina: Sistemática y Distribución. Sociedad Argentina para el Estudio de los Mamíferos, Tucumán, Argentina, pp. 31-45.

Flores, D.A. (2009). Phylogenetic analyses of postcranial skeletal morphology in didelphid marsupials. Bulletin of the American Museum of Natural History, 320, 1-81. http://dx.doi.org/10.1206/320.1

Flores, D.A., Diaz, M.M. \& Barquez, R.M. (2007) Systematics and Distribution of Marsupials in Argentina: A Review. In: Kelt, D.A., Lessa, E.P., Salazar-Bravo, J. \& Patton, J.L. (Eds.), The Quintessential Naturalist: Honoring the Life and Legacy of Oliver P. Pearson. University of California Publications in Zoology Series, 134, pp. 579-670.

Gardner, A.L. (2005) Order Didelphimorphia. In: Wilson, D.E. \& Reeder, D.M. (Eds.), Mammal Species of the World: $A$ Taxonomic and Geographic Reference, 3rd ed., The Johns Hopkins University Press, Baltimore, Maryland, pp. 3-18.

Gardner, A.L. (2008) Gazetteer of Marginal Localities. In: Gardner, A.L. (Ed.), Mammals of South America. Vol. 1. Marsupials, Xenarthrans, and Bats. The University of Chicago Press, Chicago, Illinois, pp. 581-628.

Gervais, P. (1955) Histoire Naturelle de Mammifères, avec l'Indication de leurs Moeurs, et de leurs Rapports avec les Arts, le Commerce et l'Agrículture, 2. L. Curmer, Paris, 1-3 unnumbered, 344 pp. +69 pls.

Gilmore, R.M. (1941) Zoology. In: Bugher, J.C., Boshell-Manrique, J., Roca-Garcia, M. \& Gilmore, R.M. (Eds.), The susceptibility to yellow fever of the vertebrates of eastern Colombia. 1. Marsupialia. The American Journal of Tropical Medicine, 21, 314-319.

Goeldi, E.A. (1893) Os Mammiferos do Brasil. Livraría Classica de Alves \& Co., Rio de Janeiro, iv + 182 pp.

Goeldi, E.A. (1894). Critical gleanings on the Didelphyidae of the Serra dos Orgãos, Brazil. Proceedings of the Zoological Society of London, 1894, 457-467.

Goin, F.J. \& Rey, P. (1997) Sobre las afinidades de Monodelphis Burnett, 1830 (Mammalia: Marsupialia: Didelphidae: Marmosinae). Neotropica, 43, 93-98.

Goloboff, P., Farris, J.S. \& Nixon, K. (2004) TNT: tree analysis using new technologies. Program and documentation. Available from www.cladistics.org (accessed 3/15/11).

Gomes, N.F. (1991) Revisão sistemática do gênero Monodelphis. Master’s Thesis, Universidade de São Paulo, 6 unnumbered pp. $+174+177-180+16$ tables on 30 pp. +3 pls. +34 figs + maps $1-3,5-6$.

Gruber, K.F., Voss, R.S. \& Jansa, S.A. (2007) Base-compositional heterogeneity in the RAG1 locus among didelphid marsupials: implications for phylogenetic inference and the evolution of GC content. Systematic Biology, 56, 1-14. http://dx.doi.org/10.1080/10635150601182939

Gutiérrez, E.E., Jansa, S.A. \& Voss, R.S. (2010) Molecular systematics of mouse opossums (Didelphidae: Marmosa): Assessing species limits using mitochondrial DNA sequences, with comments on phylogenetic relationships and biogeography. American Museum Novitates, 3692, 1-22. http://dx.doi.org/10.1206/708.1

Hall, T.A. (1999) BioEdit: A user-friendly biological sequence alignment editor and analysis program for Windows 95/98/NT. Nucleic Acids Symposium Series, 41, 95-98.

Hershkovitz, P. (1992) The South American gracile mouse opossums, genus Gracilinanus Gardner and Creighton, 1989 (Marmosidae, Marsupialia): A taxonomic review with notes on general morphology and relationships. Fieldiana: Zoology, new series, 70 , frontispiece $+\mathrm{i}-\mathrm{vi}+1-56$.

Ihering, H.von (1894) Os Mammiferos de S. Paulo. Catálogo. Typographia do Diário Official, São Paulo, 30 pp.

Jansa, S.A. \& Voss, R.S. (2000) Phylogenetic studies on didelphid marsupials. I. Introduction and preliminary results from nuclear IRBP gene sequences. Journal of Mammalian Evolution, 7, 43-77.

http://dx.doi.org/10.1023/A:1009465716811

Jansa, S.A. \& Voss, R.S. (2005) Phylogenetic relationships of the marsupial genus Hyladelphys based on nuclear gene sequences and morphology. Journal of Mammalogy, 86, 853-865. http://www.bioone.org/doi/abs/10.1644/1545-1542\%282005\%2986\%5B853\%3APROTMG\%5D2.0.CO\%3B2

Jansa, S.A., Forsman, J.F. \& Voss, R.S. (2006) Different patterns of selection on nuclear genes IRBP and Dmp1 affect the efficiency but not the outcome of phylogeny estimation for didelphid marsupials. Molecular Phylogenetics and Evolution, $38,363-380$. http://dx.doi.org/10.1016/j.ympev.2005.06.007

Kirsch, J.A.W. \& Calaby, J.H. (1977) The species of living marsupials: An annotated list. In: Stonehouse, B. \& Gilmore, D. (Eds.) The Biology of Marsupials. University Park Press, Baltimore, pp. 9-26. 
Lesson, R.-P. (1842) Nouveau Tableau du Règne Animal. Mammifères. Arthus-Bertrand, Paris, $204+4$ unnumbered pp.

Lim, B.K., Engstrom, M.D., Patton, J.C. \& Bickham, J.W. (2010) Molecular phylogenetics of Reig's short-tailed opossum (Monodelphis reigi) and its distributional range extension into Guiana. Mammalian Biology, 75, 287-293. http://dx.doi.org/10.1016/j.mambio.2009.03.009

Lydekker, R. (1894) A Handbook to the Marsupialia and Monotremata. Allen's Naturalist's Library: W.H. Allen \& Co., Limited, London, xvi +302 pp. +38 pls.

Lydekker, R. (1896) A Hand-book to the Marsupialia and Monotremata. Edward Lloyd, Limited, London, xvi + 320 pp. +38 pls.

Martin, R.E., Pine, R.H. \& DeBlase, A.F. (2001) A Manual of Mammalogy with Keys to Families of the World, Third Edition. McGraw-Hill, New York, New York, i, ii-v, vii-xi, xiii-xv +333 pp.

Massoia, E., Forasiepi, A. \& Teta, P. (2000) Los Marsupiales de la Argentina. Editorial L.O.L.A [Literature of Latin America], Buenos Aires, 71 pp.

Matschie, P. (1916) Bemerkungen über die Gattung Didelphis L. Sitzungsberichte der Gesellschaft Naturforschender Freunde zu Berlin, 1916, 259-272.

Miranda-Ribeiro, A.de (1935) Fauna de Terezopolis. Boletim do Museo Nacional do Rio de Janeiro, 11 (3-4), 1-40 + 16 pls., 2 maps.

Miranda-Ribeiro, A.de (1936) Didelphia ou Mammalia-ovovivipara. Marsupiaes, didelphos, pedimanos ou metatherios. Revista do Museo Paulista, São Paulo, 20, 245-427+ 8 pls.

Muirhead, L. (1819) Mazology. In: Brewster, D. (Ed.), The Edinburgh Encyclopaedia, 4th ed., William Blackwood, Edinburgh, pp. $393-486+$ pls. $353-58$.

Olrog, C.C. \& Lucero, M.M. (1981) Guía de los Mamíferos Argentinos. Fundación Miguel Lillo, Ministerio de Cultura y Educación, San Miguel de Tucumán, Argentina, 151 pp.

Patton, J.L. \& Costa, L.P. (2003) Molecular phylogeography and species limits in rainforest didelphid marsupials of South America. In: Jones, M.E., Dickman, C.R. \& Archer, M. (Eds.) Predators with Pouches: The Biology of Carnivorous Marsupials. CSIRO Publishing, Collingwood, Australia, pp. 63-81.

Pavan, S.E., Rossi, R.V. \& Schneider, H. (2012) Species diversity in the Monodelphis brevicaudata complex (Didelphimorphia: Didelphidae) inferred from molecular and morphological data, with the description of a new species. Zoological Journal of the Linnean Society, 165, 190-223. http://dx.doi.org/10.1111/j.1096-3642.2011.00791.x

Pelzeln, A.von (1883) Brasilische Säugethiere. Resultate von Johann Natterer's Reisen in den Jahren 1817 bis 1835. Verhandlungen der Kaiserlich-Königlichen Zoologisch-botanischen Gesellschaft in Wien, 33 (Suppl.), 1-140.

Pine, R.H. (1976) Monodelphis umbristriata (A. de Miranda-Ribeiro) is a distinct species of opossum. Journal of Mammalogy, $57,785-87$. http://dx.doi.org/10.2307/1379459

Pine, R.H. (1980) Taxonomic notes on "Monodelphis dimidiata itatiayae (Miranda Ribeiro)," Monodelphis domestica (Wagner) and Monodelphis maraxina Thomas (Mammalia: Marsupialia: Didelphidae). Mammalia, 43, 495-499.

Pine, R.H. (1981) Review of the mouse opossums Marmosa parvidens Tate and Marmosa invicta Goldman (Mammalia: Marsupialia: Didelphidae) with description of a new species. Mammalia, 45, 55-70. http://dx.doi.org/10.1515/mamm.1981.45.1.55

Pine, R.H. \& Abravaya, J.P. (1978) Notes on the Brazilian opossum Monodelphis scalops (Thomas) (Mammalia: Didelphidae). Mammalia, 42, 379-382.

Pine, R.H. \& Handley, C.O., Jr. (2008) Genus Monodelphis Burnett, 1830. In: Gardner, A.L. (Ed.), Mammals of South America, Vol.1. Marsupials, Xenarthrans, Shrews, and Bats. The University of Chicago Press, Chicago, pp. 82-107.

Pine, R.H., Dalby, P.L. \& Matson, J.O. (1985) Ecology, postnatal development, morphometrics, and taxonomic status of the short-tailed opossum, Monodelphis dimidiata, an apparently semelparous annual marsupial. Annals of the Carnegie Museum, 54, 195-231.

Reig, O.A. (1957) Sobre la posición sistematica de Zygolestes paranensis Amegh. y de Zygolestes entrerrianus Amegh. con una reconsideración de la edad y correlación del "Mesopotamiense". Holmbergia, 5, 210-226.

Reig, O.A., Kirsch, J.A.W. \& Marshall, L.G. (1987) Systematic relationships of the living and Neocenozoic American "opossum-like" marsupials (Suborder Didelphimorphia), with comments on the classification of these and of the Cretaceous and Paleogene New World and European metatherians. In: Archer, M. (Ed.), Possums and Opossums: Studies in Evolution, Vol. 1, Surrey Beatty \& Sons Pty Limited and Royal Society of New South Wales, Sydney, Australia, pp. 189.

Ridgway, R. (1912) Color Standards and Color Nomenclature. Privately Published, Washington, D.C., iv +44 pp. +53 pls.

Rossi, R.V., Voss, R.S. \& Lunde, D.P. (2010) A revision of the didelphid marsupial genus Marmosa part 1.The species in Tate's 'mexicana' and 'mitis' sections and other closely related forms. Bulletin of the American Museum of Natural History 334: $1-83$. http://dx.doi.org/10.1206/334.1

Solari, S. (2007) New species of Monodelphis (Didelphimorphia: Didelphidae) from Peru, with notes on M. adusta (Thomas, 1897).Journal of Mammalogy, 88, 319-329. http://dx.doi.org/10.1644/06-MAMM-A-075R1.1 
Solari, S. (2010) A molecular perspective on the diversification of short-tailed opossums (Monodelphis: Didelphidae). Mastozoología Neotropical, 17, 317-333.

Solari, S. \& Pine, R.H. (2008) Rediscovery and redescription of Marmosa (Stegomarmosa) andersoni Pine (Mammalia: Didelphimorphia: Didelphidae), an endemic Peruvian mouse opossum, with a reassessment of its affinities. Zootaxa, 1756, 49-61.

Solari, S., Pacheco, V., Vivar, E. \& Emmons, L.E. (2012) A new species of Monodelphis (Mammalia: Didelphimorphia: Didelphidae) from the montane forests of central Perú. Proceedings of the Biological Society of Washington, 125, 295307. http://dx.doi.org/10.2988/11-33.1

Thomas, O. (1888) Catalogue of the Marsupialia and Monotremata in the Collection of the British Museum (Natural History). British Museum (Natural History), London, xiv +401 pp. +38 pls.

Trouessart, E.-L. (1898-1899) Catalogus Mammalium tam Viventium quam Fossilium. Fasciculus V. Sirenia, Cetacea, Edentata, Marsupialia, Allotheria, Monotremata. R. Friedländer \& Sohn, Berolini, 2, 999-1264.

Trouessart, E.-L. (1904-1905) Catalogus Mammalium tam Vivientium quam Fossilium. Quinquennale Supplementum, Anno 1904. R. Friedländer \& Sohn Berolini, i-vii + i-iv + 1-929 pp.

Vanzolini, P.E. (1993) As viagens de Johann Natterer no Brasil. Papéis Avulsos de Zoologia, 38, 17-60.

Vieira, C.O.da C. (1950) Xenartros e marsupiais do estado de São Paulo. Arquivos de Zoologia do Estado de São Paulo, 7 , $325-362$.

Vieira, C.O.da C. (1955) Lista remissiva dos mamíferos do Brasil. Arquivos de Zoologia do Estado de São Paulo, 8, $341-474$.

Vilela, J.F., Russo, C.A.de M. \& Oliveira, J.A.de (2010) An assessment of morphometric and molecular variation in Monodelphis dimidiata (Wagner, 1847) (Didelphimorphia: Didelphidae). Zootaxa, 2646, 26-42.

Voss, R.S. \& Jansa, S.A. (2003) Phylogenetic studies on didelphid marsupials II. Nonmolecular data and new IRBP sequences: Separate and combined analyses of didelphine relationships with denser taxon sampling. Bulletin of the American Museum of Natural History, 276, 1-82. http://hdl.handle.net/2246/444

Voss, R.S. \& Jansa, S.A. (2009) Phylogenetic relationships and classification of didelphid marsupials, an extant radiation of New World metatherian mammals, Bulletin of the American Museum of Natural History, 322, 1-177. http://dx.doi.org/10.1206/322.1

Voss, R.S., Pine, R.H. \& Solari, S. (2012) A new species of the didelphid marsupial genus Monodelphis from eastern Bolivia. American Museum Novitates, 3740, 1-14. http://dx.doi.org/10.1206/3740.2

Wagner, J.A. (1842) Diagnosen neuer Arten brasilischer Säugthiere. Archiv für Naturgeschichte, 8, 356-362.

Wagner, J.A. (1847) Beiträge zur Kenntniss der Säugthiere Amerika's, Erste Abtheilung. Abhandlungen der MathematischPhysikalischen Klasse der Königlich Bayerischen Akademie der Wissenschaften zu München, 5, 121-208 + 3 pls.

Wagner, J.A. (1853-1855) Die Säugthiere in Abbildungen nach der Natur mit Beschreibungen von Dr. Johann Christian Daniel von Schreber. Supplementband. Fünfte Abtheilung: Die Affen, Zahnlücker, Beutelthiere, Hufthiere, Insektenfresser und Handflügler, T.O. Weigel, Leipzig, 5, xxvi +810 pp. +51 pls.

Waterhouse, G.R. (1846) A Natural History of the Mammalia. Hippolyte Bailliere, Publisher, London, 1,2 unnumbered +553 pp. +22 pls.

Wible, J.R. (2003) On the cranial osteology of the short-tailed opossum Monodelphis brevicaudata (Didelphidae, Marsupialia). Annals of the Carnegie Museum,72, 137-202.

\section{APPENDIX 1.}

The skins and skulls examined are deposited in the following collections, listed in alphabetical order by their acronyms: AMNH, American Museum of Natural History, New York, USA; BMNH, Natural History Museum, London, UK; CML, Colección Mamíferos Lillo, Tucumán, Argentina; IADIZA, Instituto Argentino de Investigaciones en Zonas Áridas, Mendoza, Argentina; MACN, Museo Argentino de Ciencias Naturales "Bernardino Rivadavia," Buenos Aires, Argentina; MLP, Museo de La Plata, La Plata, Argentina; MMP, Museo Municipal Lorenzo Scaglia, Mar del Plata, Argentina; CFA, Colección Mastozoología Fundación Félix de Azara, Buenos Aires, Argentina; NMW, Naturhistorisches Museum Wien, Austria; RMNH, Rijksmuseum van Natuurlijke Historie, Leiden, Netherlands. Some coordinates from Gardner (2008).

Monodelphis americana (2): BRAZIL: São Paulo: Ipanema near Sorocaba, 23 30' S, 47 32' W (NMW B 2609); Pará: Benevides, 1² $1^{\prime} \mathrm{S}, 48^{\circ} 14^{\prime} \mathrm{W}$ (AMNH 37490).

Monodelphis brevicaudata (17): locality unknown (BMNH 88.1.31.1, Holotype); localities unknown (RMNH 18079, 12851, 17907); SURINAME: locality unknown (RMNH 12851, 17907); BRAZIL: Roraima: Limão, $3^{\circ} 55^{\prime} \mathrm{N}, 60^{\circ} 29^{\prime} \mathrm{W}$ (AMNH 75520); VENEZUELA: Amazonas, Atabapo, $3^{\circ} 53^{\prime} \mathrm{N}, 66^{\circ} 48^{\prime} \mathrm{W}$ (AMNH 77565); Atures, $5^{\circ} 41^{\prime} \mathrm{N}, 67^{\circ} 17^{\prime} \mathrm{W}$ (AMNH 78094); Casiquiare, $2^{\circ} 53^{\prime} \mathrm{N}, 66^{\circ} 02^{\prime} \mathrm{W}$ (AMNH 78096); Bolivar: Mount Roraima, $5^{\circ} 09^{\prime} \mathrm{N}, 60^{\circ} 46^{\prime} \mathrm{W}$ (AMNH 75682, 75683,75684 ); Sororopan-tepui, $5^{\circ} 45^{\prime} \mathrm{N}, 60^{\circ} 43^{\prime} \mathrm{W}$ (AMNH 176318); Cerro Auyan-tepui, $5^{\circ} 48^{\prime} \mathrm{N}, 62^{\circ} 28^{\prime} \mathrm{W}$ (AMNH 130569, 130573, 130574).

Monodelphis dimidiata (48): ARGENTINA: Buenos Aires: Abra de la Ventana, 3809' S, 61 48’ W (MACN 14954, 14961, 
15718, 15719); Arroyo Brusquitas, $38^{\circ} 16^{\prime} \mathrm{S}, 5^{\circ}$ 51' W (MACN 24457, MLP 27.X.95.7, CFA 903, 904); Arroyo La Bomba, Gral. Pueyrredon, $37^{\circ} 56^{\prime} \mathrm{S}, 57^{\circ} 46^{\prime} \mathrm{W}$ (MACN 24458, CFA 6904); Balneario Sierra Grande, 8 km E de Monte Hermoso, $38^{\circ} 59^{\prime} \mathrm{S}, 61^{\circ} 03^{\prime} \mathrm{W}$ (MMP 8526, 8528, 8535, 8538); General Alvarado, $38^{\circ} 16^{\prime} \mathrm{S}, 5^{\circ}$ 51' W (MLP 7.IV.96.1);

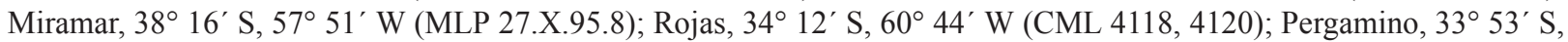
$60^{\circ} 36^{\prime} \mathrm{W}$ (CML 4122, MACN 18734, 18998, 24453, 24454, MMP 154, 155, 160, 161, CFA 2715), Curva de Peña, Ruta

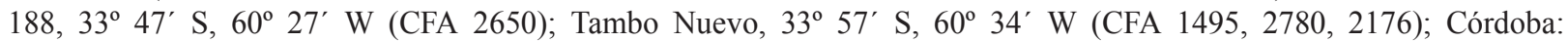
Calamuchita, Yacanto, $32^{\circ} 07^{\prime} \mathrm{S}, 64^{\circ} 45^{\prime} \mathrm{W}$ (MACN 14751, 14752, 14755, 14756), Santa Fe: Maximo Paz, 33 $30^{\prime} \mathrm{S}, 60^{\circ}$

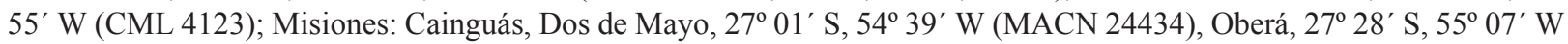
(MACN 24439), Los Helechos, $27^{\circ} 32^{\prime} \mathrm{S}, 5^{\circ} 05^{\prime} \mathrm{W}$ (MACN 24444); Montecarlo, $26^{\circ} 34^{\prime} \mathrm{S}, 54^{\circ} 46^{\prime} \mathrm{W}$ (MACN 24445);

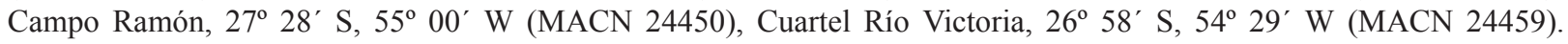

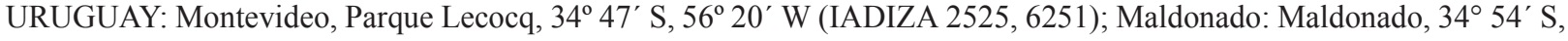

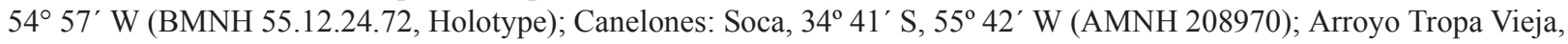
$34^{\circ} 47^{\prime} \mathrm{S}, 55^{\circ} 52^{\prime} \mathrm{W}$ (MACN 24440).

Monodelphis domestica (8): BRAZIL: Mato Grosso: Cuiabá, $15^{\circ} 32^{\prime} \mathrm{S}, 5^{\circ} 05^{\prime} \mathrm{W}$ (but see Gardner, 2008: 594) ( NMW B 2608, BMNH 87.10.25.1, Syntypes); ARGENTINA: Formosa: Ingeniero Juárez, 23 54' S, 61 51' W (CML727); Reserva Natural Formosa: Paso de los Coyas, Río Bermejito, 24 19' S, 61 43' W (MACN 20492); PARAGUAY: Boquerón: 50 kilometers west southwest of Fortín Madrejón, Cerro León, 21 $02^{\prime} \mathrm{S}, 60^{\circ} 15^{\prime} \mathrm{W}$ (AMNH 348302); BOLIVIA: Chiquisaca: Porvenir, 20 50’ S, 63 10’ W (AMNH 261231, 261233, 261234).

Monodelphis glirina (1): BRAZIL: Rôndonia: Cachoeira de Pau Grande, Rio Mamore (somewhat south of Villa Murtinho), $10^{\circ}$ 20’ S, 65 20’ W (but see Gardner, 2008: 599) ( NMW B 2626, Holotype).

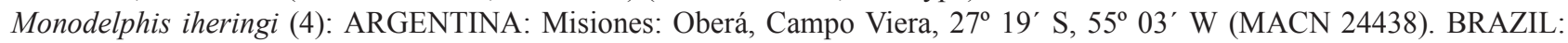
Bahia: Ilhéus, $14^{\circ} 47^{\prime} \mathrm{S}, 39^{\circ} 03^{\prime} \mathrm{W}$ (MACN 17284); Santa Catarina: Joinville, $26^{\circ} 18^{\prime} \mathrm{S}, 48^{\circ} 50^{\prime} \mathrm{W}$ (RMNH 2226); Rio Grande do Sul: Taquara, $29^{\circ} 39^{\prime} \mathrm{S}, 50^{\circ} 47^{\prime} \mathrm{W}$ (BMNH 82.9.30.43, Holotype).

Monodelphis kunsi (3): ARGENTINA: Salta: Campo Largo, Km. 74,5 de la ruta entre Acambuco y Campo Largo, 22 ${ }^{\circ} 01^{\prime} \mathrm{S}$, $63^{\circ} 55^{\prime} \mathrm{W}$ (MACN 23783); Aprox. $1 \mathrm{Km}$. ENE de Puesto las Vertientes, 22 $2^{\circ} 01^{\prime} \mathrm{S}, 63^{\circ} 44^{\prime} \mathrm{W}$ (MACN 23784). BOLIVIA: Tarija, Tapecua, $21^{\circ} 26^{\prime} \mathrm{S}, 63^{\circ} 55^{\prime} \mathrm{W}$ (AMNH 263968)

Monodelphis scalops (3): ARGENTINA: Misiones: Parque Nacional Iguazú, Sendero Yacantiá, 25 $41^{\prime} \mathrm{S}, 54^{\circ} 27^{\prime} \mathrm{W}$ (MACN

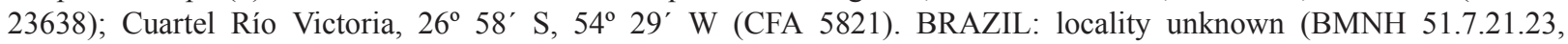
Holotype).

“Monodelphis sorex" (13): ARGENTINA: Misiones: Arroyo Urugua-í, 25 54' S, 54 36 36 W (MACN 18882, 52.52, 52.58); Dos de Mayo, $27^{\circ} 02^{\prime} \mathrm{S}, 54^{\circ} 38^{\prime} \mathrm{W}$ (MACN 1861, 1862, CFA 4518); Eldorado, 26 $23^{\prime} \mathrm{S}, 54^{\circ} 37^{\prime} \mathrm{W}$ (CML 913, 1860);

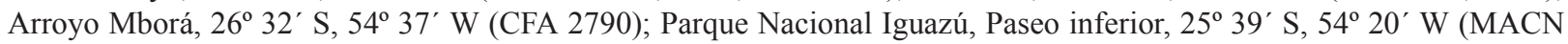

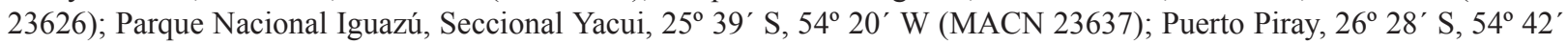
W (MACN 52.70, 51.177). BRAZIL: Rio Grande do Sul (NMW B 2618).

\section{APPENDIX 2.}

Scoring of morphological characters for species of Monodelphis, based on the data-matrix defined by Voss and Jansa (2009) and by Flores (2009), is as follows:

M. unistriata. Voss and Jansa (2009): (1-10): ???00 0-018; (11-20): 00000 00000; (21-30): 00010 0-???; (31-40): ?2010 00000; (41-50): 00001 0101?; (51-60): ?0-00 ?????; (61-70): ?0101 0001?; (71-80): ????? ?????; (81-90): ????? 1?000; (91-100): 00000 021?0; (101-110): 01002 100?1; (111-120): 00002 ?0000; (121-129): 11100 ????.

M. dimidiata. Voss and Jansa (2009): (1-10): 01000 0-004; (11-20): 00000 00000; (21-30): 00010 0-0?0; (31-40): 02000 00000; (41-50): 00001 01010; (51-60): 10-00 00011; (61-70): 00100 00010; (71-80): 01200 00000; (81-90): 10011 10000; (91-100): 00000 02100; (101-110): 01002 00000; (111-120): 00012 00001; (121-129): 11001 ????.

M. domestica. Voss and Jansa (2009): (1-10): 01000 0-000; (11-20): 00000 00000; (21-30): 00010 0-0?0; (31-40): 02000 00000; (41-50): 00001 01010; (51-60): 10-00 01011; (61-70): 00100 00010; (71-80): 01200 00000; (81-90): 10011 10000; (91-100): 00000 02100; (101-110): 01002 00000; (111-120): 00002 00001; (121-129): 11001 ????.

M. iheringi. Voss and Jansa (2009): (1-10): 01000 0-003; (11-20): 00000 00000; (21-30): 00010 0-0?0; (31-40): 02010 00000; (41-50): 00001 01010; (51-60): 10-00 00011; (61-70): 00100 00010; (71-80): 01000 00000; (81-90): 10011 10000; (91100): 00000 02100; (101-110): 01002 00000; (111-120): 00012 00001; (121-129): 11001 ????.

M. kunsi. Voss and Jansa (2009): (1-10): 01000 0-010; (11-20): 00000 00000; (21-30): 00010 0-0?0; (31-40): 00000 00000; (41-50): 00001 01010; (51-60): 10-00 01011; (61-70): 10100 00010; (71-80): 01200 00000; (81-90): 10011 00000; (91100): 00000 21000; (101-110): 10021 00?00; (111-120): 00020 00001; (121-129): 110010101. Flores (2009): (1-10): 00012 11201; (11-20): 11011 01001; (21-30): 00011 00342; (31-40): 1000100111 ; (41-50): 01030 --010; (51-60): 10101 10100; (61-70): 11001 10111; (71-80): 01131 01100; (81-90): 00001 00110; (91-100): 10010 01110; (101-110): 00111 10001; (111-114): 0010.

M. scalops. Voss and Jansa (2009): (1-10): 01000 0-014; (11-20): 00000 00000; (21-30): 00010 0-010; (31-40): 00000 00000; (41-50): 00001 01010; (51-60): 10-00 01011; (61-70): [01]0100 00010; (71-80): 01000 10000; (81-90): 10011 00000; 
(91-100): 00000 21000; (101-110): $1002100 ? 00$; (111-120): 00020 00001; (121-129): 11001 ????.

M. sorex. Voss and Jansa (2009): (1-10): ?1000 0-000; (11-20): 00000 00000; (21-30): 00010 0-???; (31-40): ?0000 00000; (41-50): 00001 01010; (51-60): 1[01]1[01][01] 02011; (61-70): [01]0100 00[01]10; (71-80): 01000 00000; (81-90): 10011 00000; (91-100): 00000 21?00; (101-110): 10021 00?00; (111-120): 0002? 00001; (121-129): 11000 ????.

\section{APPENDIX 3.}

\section{Abbreviated Taxonomic History of Monodelphis unistriata}

The complete original description by Wagner (1842:360) reads, "16. Didelphys unistriata Natt. Didelphys supra ferruginea, cano-mixta, subtus rufescens, stria dorsali obscuriori, cauda abbreviata piliosiuscula. Corpus 5 1/4 ", cauda $11 / 2$ ". Ytarare". We assume that the unit of measurement was the Prussian inch or Zoll $=2.6154 \mathrm{~cm}$ according to Goeldi (1894). This would make the "corpus" measurement ca. $137 \mathrm{~mm}$ and the "cauda" ca. $39 \mathrm{~mm}$. Waterhouse (1846:513) wrote of Didelphys unistriata: "Length of the body $5 \frac{1 / 4}{4}$ inches [= $133.35 \mathrm{~mm}$ ]; of tail, $2 \frac{1 / 2}{2}$ inches [= $\left.63.5 \mathrm{~mm}\right]$ ". Wagner (1847:148) continued to attribute the name Didelphys unistriata to "NATT." (= Johann Natterer), as did Pelzeln (1883:116), and provided a longer Latin diagnosis than previously, which we have translated as "A D[idelphys] that is rust-colored and whitish gray above, below and laterally rusty-reddish; with a depressed dark dorsal stripe; head shortened; ear short; tail shorter than half the body and with small hairs; animal as a whole very short-haired."

Wagner (1847:148-150) stated the animal was similar to Didelphys glirina (= Monodelphis glirina, also named by Wagner) but somewhat smaller and with tail of a different nature ("von anderer Beschaffenheit"). This time, Wagner provided a long German description with a few measurements. A very free translation, with omissions, and delivered in telegraphic style, is as follows: "Body elongate, legs short, head somewhat thick and short. Rhinarium sulcate; facial vibrissae short and delicate; ears small, not extending up above crown of head, half-rounded, emarginated below, essentially naked, but with a delicate scattering of hairs. Front feet more robust than delicate and small hind ones. Tail not half as long as body, covered at base somewhat by backhair, from there to tip somewhat thickly covered with erect little hairs [abstehenden Härchen ziemlich dicht besetzt] Compared with tails of 'D. glirina' and 'D. velutina' [=Thylamys velutinus (Wagner)]; that of unistriata not as thick at base and, in particular, not cone-shaped; pelage not pressed together but standing out and coarser; tail not stretched straight out but near tip chopped-off bent [nicht...gerade augestrekt, sondern am untern Ende hakenförmig eingekrümmt]. [This bend, said not to be found in certain other small opossums, was taken by Wagner as evidence that the tail of unistriata was used for grasping, a view he thought to be confirmed by the hair on the underside of the tail tip being supposedly more pressed together ("mehr angedrückt") than in the other species]. Scrotum heavily haired, (overall?) pelage dense [sehr kurz angedrückt] but not soft [fühlt sich nicht weich an], dorsally rust-brown-red with fine white sprinkling. Entire lateral area and entire underside unicolored-pale rusty-red, sharply demarcated from dorsal coloration, somewhat brighter ventrally. From shoulders to base of tail, a somewhat depressed, thin, uniformly dark rustbrown stripe. Dorsal pelage gray basally, then golden with rust-brown-red tips. Hairs on flanks and belly self-colored, but somewhat paler toward base. Facial vibrissae blackish, cheek clefts whitish. Limbs reddish like flanks, but with sprinkled dorsal pelage extending down somewhat on outer side of hind limbs. Claws golden white with dark flecks. Tail dark rustbrown dorsally, dirty rust-gold covered with hair ventrally, black scrotum covered with rust-golden hairs, and soles in life appeared to be 'flesh-colored' [fleischfarben]. Body length 5 " 7 "'[presumably = 57/12 Prussian Zoll = ca. 146 mm]; tail, 2 " 5 "'[= ca. $63 \mathrm{~mm}]$; nose to eye, 0 " $61 / 2$ "'[= ca. $14 \mathrm{~mm}]$; nose to ear, 1 " 1 "'[= ca. $28 \mathrm{~mm}]$; ear, 0 " 5 "'[ = ca. 11 $\mathrm{mm}$ ], hind foot, $0 " 63 / 4 " '=c a .15 \mathrm{~mm}] "$. How these measurements were taken is not clear to us. In particular, one wonders if the rhinarium was included in the "nose to" measurements. Wagner later (1855) repeated his Latin description of this species, but omitted any mention of relative tail length in his German redescription.

Burmeister (1856:87), wrote about [Didelphys] Microdelphys unistriata, describing it as with "Rückenseite röthlichgrau, mit schwarzlichem Längsstreif; Unterfläche blass rostgelbroth; Schwanz kurz, dicht fein behaart—Kopf and Körper 5 " 3 "' Schwanz 2 " 3 "'-Von Itarary in St. Paulo" (Dorsally reddish-gray with blackish lengthwise stripe; under surface pale rusty orange; tail short, thickly covered with fine hair-head and body ca. $137 \mathrm{~mm}$, tail ca. $59 \mathrm{~mm}$. From Itarary in São Paulo).

Pelzeln's (1883:116) redescription was based solely on Natterer's field notes on the holotype (S. Engelberger, in litt.), stating it came "aus der Steppe bei Ytararé," and that it was taken on 11 March 1821, had been found by a bird dog, seemed to show little fear, and moved very slowly. A free translation is as follows: "Jaws elongated, giving elongate form to head, but head broad and rounded toward rear. Sides of head, lower jaw, upper and lower surfaces of front feet, lower flanks, entire belly, inner side of hind feet, and underside of tail dark blond ["dunkel semmelfarben" according to Pelzeln-Natterer had written "dunkel semmelfarben, oder licht zimmetfarben" (=...cinnamon-colored)]. Rest of body a finely mixed dark chestnut brown and whitish. A thin dark chestnut-brown stripe extending from shoulders to base of tail. Hair short and fairly stiff-feeling. Fur of underside of head and belly somewhat more sparse; facial vibrissae very few. Pinnae very short, rounded, covered with very small, fine hairs. Height of ear from crown 2 "'[presumably Austrian-style measurements and therefore $=c a .4 .4 \mathrm{~mm}]$. Teeth difficult to see, owing to skull being inside skin. Lower canine $11 / 2$ "' $[=c a .3 .3 \mathrm{~mm}]$ long, upper canine somewhat longer. 'Tarsen' and toes of all feet short and small, their upper sides with minute hairs; length of manus [wrist joint to tip of longest claw of middle digit] $5^{\prime \prime \prime}[=c a .11 \mathrm{~mm}$.]; digits 2,3 , and 4 of about equal length, digits 
1 and 5 also of about the same [presumably lesser] length; claws short, sharp, little curved. Tail covered with short dense hairs, with those at its base somewhat longer. Length of hind foot [including calcaneum?] to tip of claw of middle digit 7 "'[ =ca. $15 \mathrm{~mm}]$. Scrotum very large, 6 "' long [= ca. $13 \mathrm{~mm}]$. Total length of animal $73 / 4$ "[= ca. $204 \mathrm{~mm}]$, tail2 1/2 "[= ca. $66 \mathrm{~mm}] "$.

Pelzeln did not state if external measurements were made in the flesh or of the dried skin. We take it for granted that Natterer used Austrian or (as they were more often called) Viennese measurements. In the older literature, some of the discrepancies in measurements of $M$. unistriata may be the result of authors mis-transforming Natterer's values with the help of their regional systems. The Viennese Fuß/foot $=315.6 \mathrm{~mm}$ (=12 Austrian Zoll/inches); one Zoll/inch = $26.3 \mathrm{~mm}$ (= 12 Austrian Linien/lines); one Linie/line $=2.195 \mathrm{~mm}$. Because Pelzeln's account was of a dried specimen, Pine and Handley (2008) assumed that at least part of it was based on observations he had made. However, according to S. Engelberger (in litt.), all of the information came from Natterer's notes. It seems strange that Natterer, the collector of record, provided notes on a dried specimen, rather than on the animal before it was prepared, but Engelberger hypothesizes that it may have been stuffed by an assistant of Natterer's before Natterer saw it.

Later, Thomas (1888:365-366) examined the holotype which he, in turn, also redescribed. Thomas's redescription is sufficiently brief and characteristically informative that it warrants quoting in its entirety, "Fur unusually short and coarse. General colour of upper surface pale grizzled grey, the hairs tipped with rufous; a narrow dark reddish-brown line running down the centre of the back from behind the shoulders to the rump. Flanks and whole of underside bright orange, the hairs orange to their bases; the line of demarcation not sharply marked. Ears very short and rim-like, almost naked. Arms and legs, metacarpus and metatarsus orange; fingers and toes naked. Tail with its basal half-inch furry, gradually passing into the short-haired part, brown above, yellowish below. [new paragraph] Teeth. Upper $\mathrm{p}^{4}$ apparently disproportionally larger than $\mathrm{p}^{1}$ and $\mathrm{p}^{3}$. Distance from the back of $\mathrm{p}^{4}$ to the front of the upper canines 8 millim".

Matschie (1916) placed "unistriata WAGN." in the genus "Microdelphys BURMEISTER," along with "americana MÜLL.", "alboguttatus BURM.", and "iheringi THOS". The remainder of the short-tailed opossums were placed in Monodelphis Burnett except for "sorex HENSEL" which was put in "Monodelphiops MTSCH". Microdelphys sensu Matschie was separated out in a key because of its members' dorsal stripes, but Matschie gave no other features distinguishing this supposed genus.

Miranda-Ribeiro (1936) gave a short description of what one of us (Pine) earlier assumed must have been a second individual, also a male, and which Miranda-Ribeiro referred to as "Peramys unistriatus (Natt.)". He also stated, somewhat cryptically, that he had himself had this rare animal in his own hands. Pine (as had Vieira 1950) believed initially that Miranda-Ribeiro could not be speaking of the type specimen and that he must have had a second specimen in hand because the measurements Miranda-Ribeiro gave were so different from those presented by Thomas. Bauer, however, was aware that Miranda-Ribeiro had visited the Naturhistorisches Museum Wien at least once to study Natterer's marsupials and Miranda-Ribeiro mentioned a visit in 1911 in a footnote on p. 325 of his monograph. Therefore, we assume that MirandaRibeiro saw only the holotype. As will be discussed below, the skin was apparently "reworked" between the time that Thomas saw it and Miranda-Ribeiro did - and this would have been likely to change the measurements. A brief account of this matter has been given previously by Pine and Handley (2008).

Miranda-Ribeiro described the animal's color as rusty dorsally mixed with a small amount of gray, rusty on the sides of the body and on the venter - the last being somewhat ocherous. The middorsal line is described as a fine line of a brighter rusty. He commented on the testes as being enormous ("Glandulas masculinas enormes") and gave the following external measurements: head, 38; body, 106; tail—somewhat damaged, 55; forefeet (he gave as a plural), 8; hind feet (plural), 15; testes (plural), 18; tip of the rhinarium to the eye, 9; [tip of the rhinarium] to the base of the ear, 30; ear, 9; eye, $5 \mathrm{~mm}$. The foot measurements presumably do not include the claws, and the ear measurement would presumably be European-style as well. We assume that the eye measurement is canthus to canthus. 